\title{
Antibiotic resistance and molecular epidemiology of Staphylococcus aureus in Nigeria
}

\author{
Adebayo O Shittu ${ }^{1,5^{*}}$, Kenneth Okon ${ }^{2}$, Solayide Adesida ${ }^{3}$, Omotayo Oyedara ${ }^{1,4}$, Wolfgang Witte ${ }^{5}$, \\ Birgit Strommenger ${ }^{5}$, Franziska Layer ${ }^{5}$ and Ulrich Nübel ${ }^{5}$
}

\begin{abstract}
Background: Staphylococcus aureus is an important pathogen causing a wide range of infections in the hospital and community setting. In order to have adequate information for treatment of $S$. aureus infections, it is crucial to understand the trends in the antibiotic-resistance patterns. In addition, the occurrence and changes in types of $S$. aureus, clonal identities, and their geographic spread is essential for the establishment of adequate infection control programmes. In this study, $68 \mathrm{~S}$. aureus isolates obtained from clinical and non-clinical sources in Nigeria between January and April 2009 were characterized using phenotypic and molecular methods.
\end{abstract}

Results: All the $S$. aureus isolates were susceptible to teicoplanin, vancomycin, phosphomycin, fusidic acid, rifampicin, daptomycin, mupirocin, linezolid and tigecycline. Sixteen percent of the isolates were resistant to oxacillin, while $55 \%$ and $72 \%$ of isolates were resistant to tetracycline and trimethoprim/sulphamethoxazole (cotrimoxazole), respectively (Table 1). There was excellent correlation between the broth microdilution assay and detection of antibiotic resistance genes by the multiplex PCR, in the determination of $S$. aureus resistance to erythromycin, gentamicin, methicillin and tetracycline. A total of 28 spa types were identified in the study, and the predominant spa type among the methicillin-susceptible S. aureus (MSSA) isolates was t084 (13 isolates). The t037ST241-SCCmeclll type was the only clone identified in Maiduguri (North-East Nigeria) while in South-West Nigeria, diversity among the MRSA isolates (t451-ST8-SCCmecV; t008-ST94-SCCmecIV; t002-ST5-SCCmecV; t064-ST8-SCCmecV) was observed. The toxin genes seh and etd were detected in isolates affiliated with clonal complexes CC1, CC80 and sequence type ST25, respectively. The proportion of PVL-positive isolates among MSSA was high (40\%). Most of the PVL-positive MSSA isolates were obtained from wound infections and associated with clonal complexes CC1, CC30, CC121 and with sequence type ST152.

Conclusions: The use of phenotypic and molecular methods provided useful information on antibiotic resistance and molecular diversity of S. aureus in Nigeria. The high proportion of PVL-positive MSSA isolates affiliated to various clonal complexes and detected in all the health institutions is a major concern, both as a source of severe infections and as a potential reservoir that could lead to the emergence of PVL-positive MRSA. This study presents the first baseline information on the nature of the antibiotic resistance genes from S. aureus isolates in Nigeria. There is the need to curtail the spread and establishment of MRSA and PVL-positive MSSA clones in Nigerian health care institutions.

\section{Background}

Staphylococcus aureus is a leading cause of diseases such as skin and soft tissue infections, pneumonia, bloodstream infections, osteomyelitis and endocarditis, as well as toxin-mediated syndromes like toxic shock and food poisoning [1,2]. It has developed resistance to a wide

\footnotetext{
* Correspondence: bayo_shittu@yahoo.com

'Department of Microbiology, Obafemi Awolowo University, lle-lfe, Nigeria Full list of author information is available at the end of the article
}

range of antimicrobial drugs, which complicates the treatment of infections. In particular, methicillin-resistant S. aureus (MRSA) has become a notorious etiologic agent for a wide variety of infections and it is one of the most important nosocomial pathogens worldwide [3-6]. Methicillin-susceptible S. aureus (MSSA) become MRSA through the acquisition and insertion into their genomes of a large DNA fragment known as staphylococcal chromosome cassette mec (SCCmec), which contains the
Ciomed Central

(c) 2011 Shittu et al; licensee BioMed Central Ltd. This is an Open Access article distributed under the terms of the Creative Commons Attribution License (http://creativecommons.org/licenses/by/2.0), which permits unrestricted use, distribution, and reproduction in any medium, provided the original work is properly cited. 
Table 1 Antibiotic resistance profile of S. aureus (MSSA and MRSA) from Nigeria

\begin{tabular}{llll}
\hline & \multicolumn{3}{l}{$\begin{array}{l}\text { Number } \\
\text { among: }\end{array}$} \\
Antibiotic & $\begin{array}{l}\text { MSSA } \\
(\mathbf{n}=\mathbf{5 7})\end{array}$ & $\begin{array}{l}\text { MRSA } \\
\mathbf{( n = 1 1 )}\end{array}$ & $\begin{array}{l}\text { Total } \\
\mathbf{( n}=\mathbf{6 8})\end{array}$ \\
\hline Penicillin & $49(86)$ & $11(100)$ & $60(88.2)$ \\
Oxacillin & $0(0)$ & $11(100)$ & $11(16.2)$ \\
Teicoplanin & $0(0)$ & $0(0)$ & $0(0)$ \\
Vancomycin & $0(0)$ & $0(0)$ & $0(0)$ \\
Gentamicin & $1(1.8)$ & $9(81.8)$ & $10(14.7)$ \\
Tetracycline & $27(47.4)$ & $11(100)$ & $38(55.9)$ \\
Ciprofloxacin & $12(21.1)$ & $8(72.7)$ & $20(29.4)$ \\
Moxifloxacin & $0(0)$ & $7(63.6)$ & $7(10.3)$ \\
Trimethoprim/sulfamethoxazole & $39(68.4)$ & $10(90.9)$ & $49(72.1)$ \\
Phosphomycin & $0(0)$ & $0(0)$ & $0(0)$ \\
Fusidic acid & $0(0)$ & $0(0)$ & $0(0)$ \\
Erythromycin & $2(3.5)$ & $6(54.5)$ & $8(11.8)$ \\
Clindamycin & $0(0)$ & $6(54.5)$ & $6(8.8)$ \\
Rifampicin & $0(0)$ & $0(0)$ & $0(0)$ \\
Daptomycin & $0(0)$ & $0(0)$ & $0(0)$ \\
Mupirocin & $0(0)$ & $0(0)$ & $0(0)$ \\
Linezolid & $0(0)$ & $0(0)$ & $0(0)$ \\
Tigecycline & $0(0)$ & $0(0)$ & $0(0)$ \\
\hline
\end{tabular}

methicillin resistance determinant, mecA [7]. Several variants of SCCmec have been described, which differ with respect to the composition of their recombinase genes and mec gene complex (containing the mecA gene) $[8,9]$.

In the developing world, mortality associated with severe $S$. aureus infections far exceeds that in developed countries $[10,11]$. Recent studies have identified S. aureus as the main etiological agent of many infections in sub-Saharan Africa [12-16], and a number of investigations have reported that $S$. aureus is among the most frequently encountered bacterial species in microbiology laboratories in Nigeria [17-22]. However, data on the molecular epidemiology of this pathogen in Nigeria is very limited. Recent reports have indicated that the prevalence of hospital-associated MRSA varies in health care institutions [23,24]. A community-associated MRSA clone with a unique resistance profile has also been reported from South-West Nigeria [25]. To understand and potentially predict trends in antibiotic-resistance patterns and to establish adequate infection control programs, it is crucial to understand the local epidemiology of $S$. aureus in Nigeria. Knowledge of the local antimicrobial resistance patterns of bacterial pathogens is essential to guide empirical and pathogen specific therapy. The threat of antibiotic-resistant bacteria has initiated studies on the nature of genes encoding resistance and the mechanism by which these genes spread and evolve. Antibiotic susceptibility testing of S. aureus in Nigeria is based on phenotypic testing especially the disk diffusion technique but recent studies have relied on the PCR detection of the mecA gene for the identification and confirmation of MRSA [23-26]. However, no information is available on the nature of antibiotic resistance genes of S. aureus in Nigeria. Our present study provides baseline information on antibiotic resistance and molecular epidemiology of MSSA and MRSA in Nigeria.

\section{Results}

Antibiotic susceptibility testing and detection of antibiotic resistance genes in $S$. aureus isolates

The 68 S. aureus isolates obtained between January and April 2009 were analyzed for antimicrobial resistance (Table 1). All the isolates were susceptible to teicoplanin, vancomycin, phosphomycin, fusidic acid, rifampicin, daptomycin, mupirocin, linezolid and tigecycline, and two isolates were susceptible to all the antibiotics tested. In addition to the antibiotics stated above, all MSSA isolates $(84 \%)$ were susceptible to clindamycin and moxifloxacin and less than $4 \%$ were resistant to erythromycin, $21.1 \%$ to ciprofloxacin, $47 \%$ to tetracycline, $68 \%$ to cotrimoxazole and $86 \%$ to penicillin. The predominant antibiotypes among the MSSA isolates were resistance to penicillin, tetracycline and cotrimoxazole (15 isolates), and resistance to penicillin and cotrimoxazole (13 isolates). A total of 11 isolates were resistant to oxacillin and confirmed as MRSA based on the detection of the mecA gene (Table 1). The ermA gene was identified in all erythromycin-resistant MRSA isolates, while two erythromycin-resistant MSSA isolates possessed the $m s r A$ gene. All the gentamicin-resistant isolates carried the $a a c A-a p h D$ gene. Moreover, the tet $M$ gene was detected in 11 isolates (7 MRSA and 4 MSSA) and the tetK gene was present in 4 MRSA and 23 MSSA isolates.

\section{SCCmec typing}

The SCCmec type V was identified in four MRSA isolates obtained in Ile-Ife, Ibadan and Lagos, while one MRSA isolate from Ile-Ife possessed the SCCmec type IV element (Table 2). The MRSA isolates from Maiduguri were non-typeable for the SCCmec element based on established protocols $[9,27]$, and no amplification was observed for the $c c r A, c c r B$, and $c c r h$ genes. However, these MRSA isolates possessed the $c c u$ gene. The comparison and analysis of the $c c u$ sequences from two selected MRSA isolates in this group with sequences in the GenBank suggested that the MRSA isolates possessed an SCCmec type III element of uncommon organization, which had not been identified using standard protocols. 
Table 2 Characterization of MRSA isolates from Nigeria based on antibiotic susceptibility pattern, detection of antibiotic resistance genes, SCCmec typing, spa typing and MLST

\begin{tabular}{|c|c|c|c|c|c|c|c|}
\hline $\begin{array}{l}\text { Isolate } \\
\text { No }\end{array}$ & Location & $\begin{array}{l}\text { Sample or Clinical } \\
\text { Diagnosis }\end{array}$ & Antibiotype & $\begin{array}{l}\text { Antibiotic resistance } \\
\text { genes }\end{array}$ & $\begin{array}{l}\text { SCCmec } \\
\text { type }\end{array}$ & $\begin{array}{l}\text { spa } \\
\text { type }\end{array}$ & MLST \\
\hline $09-01730$ & Ile-Ife & Chronic ulcer & PEN, OXA, GEN, OTE, SXT & mecA, aacA-aphD, tetK & $\mathrm{V}$ & t451 & 8 \\
\hline 09-01731 & Ile-Ife & Urinary tract infection & PEN, OXA, GEN, OTE & mecA, aacA-aphD, tetM & IV & t008 & $\begin{array}{l}94(8- \\
\text { slv) }\end{array}$ \\
\hline 09-01739 & Lagos & Wound infection & PEN, OXA, OTE, CIP, SXT & mecA, tetK & V & t002 & 5 \\
\hline 09-01776 & Ibadan & Conjunctivitis & PEN, OXA, OTE, SXT & mecA, tetK & V & t064 & 8 \\
\hline 09-01786 & Ibadan & Wound infection & PEN, OXA, GEN, OTE, CIP, SXT, MFL & mecA, aacA-aphD, tetK & V & t064 & 8 \\
\hline 09-01789 & Maiduguri & Wound infection & $\begin{array}{c}\text { PEN, OXA, GEN, ERY, CLI, OTE, CIP, } \\
\text { SXT, MFL }\end{array}$ & $\begin{array}{l}\text { mecA, aacA-aphD, ermA, } \\
\text { tetM }\end{array}$ & III & t037 & 241 \\
\hline $\begin{array}{l}09- \\
01791-1\end{array}$ & Maiduguri & Semen (Infertility) & $\begin{array}{c}\text { PEN, OXA, GEN, ERY, CLI, OTE, CIP, } \\
\text { SXT, MFL }\end{array}$ & $\begin{array}{l}\text { mecA, aacA-aphD, ermA, } \\
\text { tetM }\end{array}$ & \|\|$^{a}$ & t037 & 241 \\
\hline 09-01795 & Maiduguri & Throat Infection & $\begin{array}{c}\text { PEN, OXA, GEN, ERY, CLI, OTE, CIP, } \\
\text { SXT, MFL }\end{array}$ & $\begin{array}{l}\text { mecA, aacA-aphD, ermA, } \\
\text { tetM }\end{array}$ & \|\|$^{a}$ & t037 & ND \\
\hline 09-01809 & Maiduguri & Semen (Infertility) & $\begin{array}{c}\text { PEN, OXA, GEN, ERY, CLI, OTE, CIP, } \\
\text { SXT, MFL }\end{array}$ & $\begin{array}{l}\text { mecA, aacA-aphD, ermA, } \\
\text { tetM }\end{array}$ & \|\|$^{a}$ & t037 & 241 \\
\hline 09-01811 & Maiduguri & Wound Infection & $\begin{array}{c}\text { PEN, OXA, GEN, ERY, CLI, OTE, CIP, } \\
\text { SXT, MFL }\end{array}$ & $\begin{array}{l}\operatorname{mec} A, \text { aacA-aphD, ermA, } \\
\text { tetM }\end{array}$ & \|\|$^{a}$ & t037 & ND \\
\hline 09-01812 & Maiduguri & Wound Infection & $\begin{array}{c}\text { PEN, OXA, GEN, ERY, CLI, OTE, CIP, } \\
\text { SXT, MFL }\end{array}$ & $\begin{array}{l}\text { mecA, aacA-aphD, ermA, } \\
\text { tetM }\end{array}$ & \|\|$^{a}$ & t037 & ND \\
\hline
\end{tabular}

${ }^{\mathrm{a}} \mathrm{SCC}$ mec type inferred from related isolate 09-01789

slv: single locus variant

Geographical region: South-West Nigeria (Ile-Ife, Ibadan and Lagos)

North-East Nigeria (Maiduguri)

KEY

PEN: Penicillin G; OX: Oxacillin; GEN: Gentamicin; ERY: Erythromycin; CLI: Clindamycin; OTE: Tetracycline; CIP: Ciprofloxacin; SXT: Trimethoprim/sulfamethoxazole; MFL: Moxifloxacin

ND: Not determined

\section{Molecular diversity of S. aureus based on spa typing and MLST}

Twenty-eight spa types were identified in this study. Representative isolates were subsequently selected for MLST (Tables 2 and 3). Results indicated that nine major clonal complexes were represented in our strain collection from Nigeria (Tables 2 and 3). These clonal complexes plus one that we did not find (CC22) seem to predominate the $S$. aureus population on all continents. In addition, we found sequence type ST152, which has been reported previously in Ibadan and Maiduguri (Nigeria) [24,25].

\section{Detection of markers frequently associated with community-acquired S. aureus}

A total of 23 of the 57 (40.3\%) MSSA isolates (grouped in clonal complexes - CC1, CC5, CC15, CC30, CC121, CC80 and sequence type ST152) were PVL positive (Table 3), while none of the MRSA possessed the PVL gene. The enterotoxin $\mathrm{H}$ gene (seh) was detected in the isolates from clonal lineage CC1. Three MSSA isolates (ST25) from nasal samples of healthy individuals and one MSSA (CC80) from a wound infection possessed the etd gene. All the $S$. aureus isolates were $\operatorname{arcA}$ negative.

\section{Discussion}

There was excellent correlation between the broth microdilution method and detection of the genetic determinants by multiplex PCR for S. aureus resistance to erythromycin, gentamicin, methicillin and tetracycline (Tables 2 and 3). About 55\% (11 MRSA, 27 MSSA) and 70\% (10 MRSA, 39 MSSA) of the S. aureus isolates were resistant to tetracycline and cotrimoxazole, and as previous studies from South-West Nigeria had shown $[23,25]$, it appears that there is a high proportion of $S$. aureus isolates resistant to these antibiotics in Nigeria. Tetracycline and cotrimoxazole historically had wide clinical application, is inexpensive, orally administered and available from diverse sources where they are sold with or without prescription in Nigeria. Moreover, they are listed in many developing countries as among the antibacterial agents that have been rendered ineffective, or for which there are serious concerns regarding bacterial resistance [28]. It appears that misuse and overuse of these antibiotics could have contributed to this trend in Nigeria. Therefore, to prevent treatment failures in the absence of data on antibiotic susceptibility testing, public enlightenment on the ineffectiveness of these antibiotics against $S$. aureus infections, and the enactment of effective drug policies in Nigeria are urgently 
Table 3 Characterization of MSSA isolates from Nigeria by antibiotic susceptibility pattern, detection of antibiotic and virulence genes, spa typing and MLST

\begin{tabular}{|c|c|c|c|c|c|c|c|c|}
\hline $\begin{array}{l}\text { Isolate } \\
\text { No } \\
\end{array}$ & Location & $\begin{array}{l}\text { Sample Or Clinical } \\
\text { Diagnosis }\end{array}$ & Antibiotype & $\begin{array}{l}\text { Antibiotic resistance } \\
\text { genes }\end{array}$ & $\begin{array}{l}\text { Toxin } \\
\text { genes }\end{array}$ & $\begin{array}{l}\text { spa } \\
\text { type }\end{array}$ & MLST & $\begin{array}{l}\text { Clonal Complex } \\
\text { (CC) }\end{array}$ \\
\hline $09-01760$ & Ife & Wound Infection & PEN, CIP, SXT & - & lukPV, seh & $\mathrm{t} 127$ & & CC1 \\
\hline 09-01823 & Ife & Wound Infection & PEN, OTE & tetk & lukPV, seh & $\mathrm{t} 127$ & & \\
\hline $\begin{array}{l}09- \\
01785-1\end{array}$ & Ibadan & Conjunctivitis & PEN & - & lukPV, seh & $\mathrm{t} 114$ & & \\
\hline$\underline{09-01787}$ & Maiduguri & Wound Infection & PEN, OTE & tetK & seh & t321 & 1 & \\
\hline 09-01733 & Ife & Otitis media & PEN, SXT & - & lukPV & t311 & & CC5 \\
\hline 09-01738 & Lagos & Urinary tract infection & PEN, ERY, OTE, CIP, SXT & tetM, mrsA & - & t311 & 5 & \\
\hline 09-01777 & Ibadan & Wound Infection & PEN, CIP & - & - & t311 & & \\
\hline 09-01815 & Maiduguri & Otitis media & PEN, ERY, OTE, SXT & tetM, mrsA & - & t311 & & \\
\hline 09-01737 & Lagos & Semen (Infertility) & PEN, GEN, OTE, SXT & aacA-aphD, tetK & - & t951 & & CC8 \\
\hline 09-01742 & Lagos & Unknown & PEN, OTE & tetK & - & $\mathrm{t} 1617$ & 8 & \\
\hline 09-01780 & Ibadan & Conjunctivitis & PEN, SXT & - & - & t064 & & \\
\hline 09-01796 & Maiduguri & Sputum (Unknown) & PEN, OTE, SXT & tetk & - & t064 & & \\
\hline 09-01810 & Ife & Sputum (Unknown) & PEN, OTE, CIP, SXT & tetk & - & t1496 & & \\
\hline $\begin{array}{l}09- \\
01817-1\end{array}$ & Maiduguri & Urinary tract infection & PEN, OTE, SXT & tetk & - & $\mathrm{t} 1496$ & & \\
\hline 09-01819 & Maiduguri & Semen (Infertility) & PEN, OTE, SXT & tetk & - & $\mathrm{t} 2812$ & & \\
\hline 09-01822 & Ife & Sputum (Unknown) & PEN, OTE, SXT & tetk & - & t1496 & & \\
\hline 09-01734 & Ife & Unknown & PEN, OTE, SXT & tetk & - & t084 & & CC15 \\
\hline 09-01736 & Lagos & Otitis media & OTE & tetM & - & t084 & & \\
\hline $09-01750$ & Ife & Nasal* $^{*}$ & PEN, SXT & - & lukPV & t084 & & \\
\hline 09-01751 & Ife & Nasal* $^{*}$ & PEN, SXT & - & lukPV & t084 & $15-s l v$ & \\
\hline 09-01752 & Ife & Nasal* $^{*}$ & SXT & - & lukPV & t084 & & \\
\hline 09-01755 & Ife & Nasal* & PEN, OTE, SXT & tetk & - & t084 & & \\
\hline 09-01756 & Ife & Nasal* & PEN, OTE, CIP, SXT & tetk & - & t084 & & \\
\hline 09-01799 & Maiduguri & Otitis media & PEN, OTE, SXT & tetk & - & t084 & & \\
\hline 09-01801 & Maiduguri & Otitis media & PEN, OTE, SXT & tetk & - & t084 & & \\
\hline 09-01805 & Ife & Blood Infection & OTE & tetM & - & t084 & $15-s l v$ & \\
\hline 09-01820 & Ife & Wound Infection & PEN, SXT & - & - & t084 & & \\
\hline 09-01821 & Ife & Wound Infection & PEN, OTE, SXT & tetk & - & t084 & & \\
\hline 09-01824 & Ife & Wound Infection & CIP, SXT & - & - & t084 & & \\
\hline 09-01788 & Maiduguri & Wound Infection & PEN, OTE, SXT & tetk & - & $\mathrm{t} 2216$ & & \\
\hline 09-01798 & Maiduguri & Semen (Infertility) & PEN, OTE, SXT & tetk & - & t2216 & 15 & \\
\hline 09-01804 & Maiduguri & Wound Infection & PEN, OTE, SXT & tetk & - & $\mathrm{t} 2216$ & & \\
\hline 09-01806 & Ife & Unknown & PEN, SXT & - & - & t328 & & \\
\hline 09-01813 & Ife & Wound Infection & PEN, SXT & - & - & t5387 & & \\
\hline $09-01740$ & Lagos & Wound Infection & PEN, CIP, SXT & - & lukPV & t318 & & CC30 \\
\hline 09-01743 & Lagos & Wound Infection & CIP, SXT & - & lukPV & t318 & 30 & \\
\hline $\begin{array}{l}09- \\
01747-2\end{array}$ & Lagos & Wound Infection & $\begin{array}{l}\text { Susceptible to all } \\
\text { antibiotics }\end{array}$ & - & lukPV & t318 & 30 & \\
\hline 09-01779 & Ibadan & Wound Infection & PEN, CIP, SXT & - & lukPV & t021 & & \\
\hline 09-01825 & Ife & Otitis media & PEN, CIP & - & - & t631 & & \\
\hline 09-01732 & Ile-Ife & Unknown & PEN, SXT & - & lukPV & t159 & & CC121 \\
\hline 09-01759 & Ile-Ife & Wound Infection & PEN, SXT & - & lukPV & t314 & & \\
\hline 09-01797 & Maiduguri & Wound Infection & OTE & tetk & lukPV & t314 & & \\
\hline 09-01826 & Ile-Ife & Otitis media & PEN & - & lukPV & t159 & 121 & \\
\hline 09-01745 & Lagos & Semen (Infertility) & PEN, SXT & - & lukPV & t2304 & 121 & \\
\hline$\underline{09-01781}$ & Ibadan & Wound Infection & PEN, OTE, SXT & tetk & lukPV & t2304 & & \\
\hline 09-01761 & Ife & Wound Infection & PEN & - & lukPV & t355 & & singleton \\
\hline 09-01762 & Ife & Wound Infection & PEN & - & lukPV & t355 & & \\
\hline
\end{tabular}


Table 3 Characterization of MSSA isolates from Nigeria by antibiotic susceptibility pattern, detection of antibiotic and virulence genes, spa typing and MLST (Continued)

\begin{tabular}{|c|c|c|c|c|c|c|c|c|}
\hline 09-01778 & Ibadan & Wound Infection & PEN, CIP & - & lukPV & t355 & & \\
\hline 09-01790 & Maiduguri & Wound Infection & $\begin{array}{c}\text { Susceptible to all } \\
\text { antibiotics }\end{array}$ & - & - & t355 & 152 & \\
\hline 09-01793 & Maiduguri & Wound Infection & PEN & - & lukPV & t355 & & \\
\hline 09-01803 & Maiduguri & Wound Infection & PEN, OTE, SXT & tetK & lukPV & t355 & & \\
\hline 09-01753 & Ife & Nasal* & PEN, SXT & - & etd & t3772 & 25 & singleton \\
\hline 09-01754 & Ife & Nasal* & PEN, SXT & - & etd & t3772 & & \\
\hline 09-01757 & Ife & Nasal* & PEN, SXT & - & etd & $\mathrm{t} 3772$ & & \\
\hline 09-01802 & Maiduguri & Wound Infection & PEN, CIP & - & - & t939 & 45 & CC45 \\
\hline 09-01792 & Maiduguri & Wound Infection & PEN, OTE & tetk & - & t458 & 97 & CC97 \\
\hline 09-01800 & Maiduguri & Wound Infection & PEN, OTE, SXT & tetk & lukPV, etd & t934 & 80 & CC80 \\
\hline
\end{tabular}

${ }^{\mathrm{a} C l o n a l ~ c o m p l e x ~(C C) ~ i n f e r r e d ~ f r o m ~ M L S T ~ a n d ~ s p a ~ t y p i n g ~}$

*Nasal isolates from apparently healthy male students

slv: single locus variant

Geographical region: South-West Nigeria (Ile-Ife, Ibadan and Lagos)

North-East Nigeria (Maiduguri)

needed. The predominant mechanism of trimethoprim resistance in $S$. aureus appears to be mutation of the dihydrofolate reductase (DHFR), which is selected even when trimethoprim is used in combination with sulfamethoxazole [29]. In this study, all the trimethoprimresistant $S$. aureus isolates were $d f r A$ negative suggesting that mutation of the dihydrofolate reductase (DHFR) is responsible for resistance. Isolates resistant to tetracycline carried either one of the resistance genes tet $K$ or tet $M$ (Tables 2 and 3), which mediate resistance through active drug efflux or ribosomoal protection mechanisms, respectively. This is the first study that provides baseline information on the nature of the antibiotic resistance genes from $S$. aureus isolates in Nigeria. The multiplex PCR assay was easy to perform, cost-effective and assisted in the prompt characterization of the resistance genes stated above. It could be adapted for use by clinical scientists in the referral health care institutions regarding the antibiotics administered and the prevalent resistance determinants in Nigeria.

The proportion of PVL-positive isolates among MSSA was high (40\%). Most of the PVL-positive MSSA isolates were obtained from wound infections and classified in clonal complexes CC1, CC30, CC121 and ST152. Moreover, the detection of the seh gene in CC1 isolates and the identification of the etd gene in ST25 and CC80 isolates is in agreement with previous reports [27,30-32]. PVL is frequently associated with severe and recurrent skin and soft-tissue infections (SSTIs) and has previously been found in $S$. aureus isolates from various complexes. In particular, PVL-producing MSSA affiliated to CC121 are known to be common in many countries on all continents $[30,33,34]$, including Nigeria, Togo and South Africa in sub-Saharan Africa $[25,30,35]$. PVL-positive ST152 was the predominant clone in a study recently conducted in North-Eastern Nigeria [24] and it was the second most prevalent clone in a carriage study from a West-African country (Mali) [36]. Furthermore, the high prevalence of PVL positive MSSA ST152 emerging in the community as well as in hospitals in West Africa has also been described [31]. Hence, ST152 seems to be widespread and frequent in West Africa, whereas it is comparatively rare elsewhere [33,37], in contrast to many other clonal complexes that display worldwide occurrence. The $l u k-P V$ genes are carried on mobile genetic elements (prophages), which may be incorporated into $S$. aureus lineages through horizontal transfer, either before or after acquisition of the mecA gene [38]. The high proportion of PVL-positive MSSA observed in this study indicate that conditions that increase the risk of inter-individual transmission (e.g skin-to-skin and skin-to-fomite contacts) could represent important routes of spread in the various hospital settings. Contact with colonized and/or infected individuals as well as contaminated fomites in the spread of PVL positive $S$. aureus have been described as risk factors for community-associated MRSA [39]. Moreover, the detection of PVL-positive MSSA ST152 from members of one family and their relatives with skin infections at the Canary Island underscore the pathogenic and contagious nature of this clone [40]. More detailed investigations on the prevalence of PVL-positive $S$. aureus are needed in Africa with respect to (i) nasal carriage of $S$. aureus in the hospitals and community, (ii) cross-transmission from post-operative wound infections acquired during hospital stay, and (iii) cross-transmission from patients admitted to the health institutions for treatment of an SSTI acquired in the community. The detection of PVLpositive MSSA isolates from the various health institutions, indicating their wide geographical distribution, 
could pose serious problem in the future as potential reservoirs for resistance and virulence factors, and could lead to the emergence and spread of PVL-positive MRSA clones in Nigeria causing severe infections. This could have important implications for the enactment of effective infection control guidelines.

MRSA has become a major public health problem worldwide and recent reports have indicated that the prevalence of hospital-associated MRSA (based on the detection of the mecA gene) in health care institutions in Nigeria may vary from $1.5 \%$ to $20 \%$ [23-25]. All the MRSA isolates obtained from Maiduguri (North-East Nigeria) had the same spa type (t037) and MLST profile (ST241), identical to isolates from the same region that had been investigated in a previous study [24]. Another study [25] also reported that the clone was identified in a hospital in Ibadan (South-Western Nigeria). ST241 is a single locus variant (slv) of the ST239 clone, which is prevalent in South East Asia and has also been reported from Europe, the Americas [41], and several countries in Africa [6,42-44]. The multi-resistant nature of this MRSA clone could be explained by the presence of several resistance genes in the SCCmec cassette and it was recently shown to have spread across several continents since the 1960s [41]. MRSA ST239 demonstrating low level resistance to glycopeptides have been reported recently in Russia [45] and New Zealand [46]. In contrast, in South-Western Nigeria, we identified more diversity among the MRSA isolates. In three different hospitals in this region, we observed several different clones of MRSA that can be distinguished on the basis of MLST, SCCmec typing and spa typing, and displayed distinct antimicrobial resistance profiles (Table 2).

\section{Conclusions}

This study showed that the combination of susceptibility testing and various molecular methods provided useful information on the antibiotic resistance and molecular diversity of $S$. aureus in Nigeria. Although the number of $S$. aureus isolates available for our investigation and epidemiological information was limited, the high proportion of PVL-positive MSSA observed in this study indicate that adequate measures are needed to curtail the spread and establishment of MRSA and PVL-positive MSSA clones in Nigerian health care institutions.

\section{Methods}

\section{Isolation and identification of $S$. aureus isolates}

In this study, a total of 68 non-duplicate consecutive $S$. aureus isolates (60 - clinical isolates; 8 - nasal isolates; one isolate per sample per individual) obtained between January and April 2009 were characterized. The clinical isolates were obtained from samples processed in the microbiology laboratories of referral health care institutions in Ile-Ife, Ibadan and Lagos (South-West Nigeria), and Maiduguri (North-East Nigeria), each of which are 500-bed facilities providing medical care to about one million people. The clinical isolates were cultured from 30 males (median age: 31 years, range: 1 year-70 years), 21 females (median age: 36 years, range: 1 week-63 years) and 9 unknown gender. In addition, nasal isolates were obtained from apparently healthy male undergraduate students in Ile-Ife. The origin and characteristics of each isolate is stated in Tables 2 and 3. The isolates were cultured on sheep blood agar and phenotypic identification of $S$. aureus was based on colony morphology and positive plasma coagulase reaction (slide and tube test). The susceptibility testing of the isolates to 18 antibiotics was performed using the broth microdilution assay as described by Deutsches Institut für Normung [47]. The antibiotic panel included penicillin G, oxacillin, teicoplanin, vancomycin, gentamicin, tetracycline, ciprofloxacin, moxifloxacin, trimethoprim/sulfamethoxazole (cotrimoxazole), phosphomycin, fusidic acid, erythromycin, clindamycin, rifampicin, daptomycin, mupirocin, linezolid and tigecycline.

\section{DNA extraction}

Genomic DNA was obtained from a $2 \mathrm{ml}$ overnight culture using a DNeasy tissue kit (Qiagen, Hilden, Germany) with lysostaphin $(100 \mu \mathrm{g} / \mathrm{ml})$ to achieve bacterial lysis.

\section{PCR detection of the tuf gene}

Phenotypic identification of the $S$. aureus isolates was confirmed by the detection of the tuf gene [48].

\section{Multiplex PCR for detection of antibiotic resistance genes}

The antibiotic resistance determinants investigated were the aac-aphD (aminoglycoside resistance) mecA (methicillin resistance) ermA, erm C (erythromycin resistance) and tet $K$, tet $M$ (tetracycline resistance) genes. PCR primers and conditions were as described in a previously established protocol [49]. Moreover, the detection of the $d f r A$ and $m s r A$ genes (trimethoprim resistance and macrolide efflux resistance determinants) were investigated using the following primers tmpI: CTC ACG ATA AAC AAA GAG TCA; tmp II: CAA TCA TTG CTT CGT ATA ACG and $m s r A$ f: GAA GCA CTT GAG CGT TCT; $m s r A$ r: CCT TGT ATC GTG TGA TGT which amplified a 201bp and $287 \mathrm{bp}$ of the $d f r$ and $m s r A$ genes, respectively. The PCR conditions were as follows: Initial denaturation at $95^{\circ} \mathrm{C}$ for 2 minutes followed by 30 cycles of amplification with $94^{\circ} \mathrm{C}$ for 30 seconds, annealing at $50^{\circ} \mathrm{C}$ for 30 seconds, extension at $72^{\circ} \mathrm{C}$ for 30 seconds and final extension at $72^{\circ} \mathrm{C}$ for 4 minutes. 


\section{Multiplex PCR for detection of markers associated with community-acquired S. aureus}

A multiplex PCR reaction protocol [27] was used to detect markers associated with community-acquired $S$. aureus. They included the enterotoxin $\mathrm{H}$ gene (seh) for community-acquired $S$. aureus of clonal lineage ST1/ USA400, the arginine deiminase gene $(\operatorname{arc} A)$ as part of the ACME (arginine catabolic mobile element) cluster for ST8/t008/USA300, the gene for exfoliative toxin D (etd) for ST80, and the Panton-Valentine Leukocidin (PVL) gene.

\section{SCCmec typing}

SCCmec elements were classified by the multiplex PCR strategy $[9,50]$. SCCmec elements that could not be typed were characterized based on PCR amplification and sequence analysis of the cassette chromosome recombinases $\mathrm{A}$ and $\mathrm{B}$ genes ( $c c r A, c c r B)$, cassette chromosome helicase $(c c h)$ and another gene of unknown function $(c c u)$ [51].

\section{Spa typing}

Spa typing was based on the method described previously [52]. The nucleotide sequences were analyzed using the RIDOM Staph-Type software (Ridom GmbH, Germany) to assign the isolates to the various spa types.

\section{Multilocus sequence typing (MLST)}

MLST was performed according to the previously published protocol [53].

\section{Acknowledgements \\ We would like to thank the management of the hospitals for their support in the collection of the isolates. We gratefully acknowledge the technical assistance of Annette Weller, Mike Henkel, Christa Cuny, Ilona Wermuth and the staff at the Central Sequencing Unit at the Robert Koch Institute. We thank Professor Iruka Okeke for comments and suggestions on the manuscript. The stay of AOS at the Robert Koch Institute was supported by the German Ministry for Economic Cooperation and Development (DAAD award).}

\section{Author details}

'Department of Microbiology, Obafemi Awolowo University, lle-Ife, Nigeria. ${ }^{2}$ Department of Medical Microbiology, University of Maiduguri Teaching Hospital, Maiduguri, Nigeria. ${ }^{3}$ Molecular Biology and Biotechnology Division, Nigerian Institute of Medical Research, Lagos, Nigeria. ${ }^{4}$ Department of Biological Sciences, College of Science, Engineering and Technology, Osun State University, Osogbo, Nigeria. ${ }^{5}$ Robert Koch Institute, 38855 Wernigerode, Germany.

\section{Authors' contributions}

AOS, WW, BS, FL and UN conceived the study. KO, SA and $\mathrm{OO}$ participated in the preliminary identification of the isolates, AOS carried out the phenotypic and molecular characterization of the isolates. All authors read and approved the final version of the manuscript.

Received: 22 December 2010 Accepted: 5 May 2011

Published: 5 May 2011
References

1. Richards MJ, Edwards JR, Culver DH, Gaynes RP: Nosocomial infections in medical intensive care units in the United States, National Nosocomial Infections Surveillance System. Crit Care Med 1999, 27:887-892.

2. Perez-Vazquez M, Vindel A, Marcos C, Oteo J, Cuevas O, Trincado P, Bautista V, Grundmann H, Campos J, on behalf of the EARSS spa-typing Group: Spread of invasive Spanish Staphylococcus aureus spa-type 067 associated with a high prevalence of the aminoglycoside-modifying enzyme gene ant (4')-la and the efflux genes $m s r A / m s r B$. J Antimicrob Chemother 2009, 63:21-31.

3. Tiemersma EW, Bronzwaer SL, Lyytikainen O, Degener JE, Schrijnemakers $P$, Bruinsma N, Monen J, Witte W, Grundman H, European Antimicrobial Resistance Surveillance System Participants: Methicillin-resistant Staphylococcus aureus in Europe, 1999-2002. Emerg Infect Dis 2004, 10:1627-1634.

4. Huang YC, Su LH, Wu TL, Lin TY: Changing molecular epidemiology of methicillin-resistant Staphylococcus aureus bloodstream isolates from a teaching hospital in Northern Taiwan. J Clin Microbiol 2006, 44:2268-2270.

5. Sola C, Cortes P, Saka HA, Vindel A, Bocco JL: Evolution and molecular characterization of methicillin-resistant Staphylococcus aureus epidemic and sporadic clones in Cordoba, Argentina. J Clin Microbiol 2006, 44:192-200.

6. Shittu $A O$, Nübel U, Udo EE, Lin J, Gaogakwe S: Characterization of methicillin-resistant Staphylococcus aureus (MRSA) isolates from hospitals in KwaZulu-Natal (KZN) province, Republic of South Africa. J Med Microbiol 2009, 58:1219-1226.

7. Hiramatsu K, Cui L, Kuroda M, Ito T: The emergence and evolution of methicillin-resistant Staphylococcus aureus. Trends Microbiol 2001, 9:486-493.

8. Chongtrakool P, Ito T, Ma XX, Kondo Y, Trakulsomboon S, Tiensasitorn C, Jamklang M, Chavalit T, Song JH, Hiramatsu K: Staphylococcal cassette chromosome mec (SCCmec) typing of methicillin-resistant Staphylococcus aureus strains isolated in 11 Asian countries: a proposal for a new nomenclature for SCCmec elements. Antimicrob Agents Chemother 2006, 50:1001-1012.

9. Oliveira DC, Milheirico C, de Lencastre H: Redefining a structural variant of staphylococcal cassette chromosome mec, SCCmec type VI. Antimicrob Agents Chemother 2006, 50:3457-3459.

10. Nickerson EK, West TE, Day NP, Peacock : Staphylococcus aureus disease and drug resistance in resource-limited countries in South and East Asia. Lancet Infect Dis 2009, 9:130-135.

11. Nickerson EK, Hongsuwan M, Limmathurotsakul D, Wuthiekanun V, Shah KR, Srisomang P, Mahavanakul W, Wacharaprechasgul T, Fowler VG, West TE, Teerawatanasuk N, Becher H, White NJ, Chierakul W, Day NP, Peacock SJ: Staphylococcus aureus bacteraemia in a tropical setting: patient outcome and impact of antibiotic resistance. PLOS ONE 2009, 4:e4308.

12. Mulu A, Moges F, Tessema B, Kassu A: Pattern and multiple drug resistance of bacterial pathogens isolated from wound infection at University of Gondar Teaching Hospital, Northwest Ethiopia. Ethiop Med J 2006, 44:125-131.

13. Feleke $Y$, Mengistu $Y$, Enquselassie F: Diabetic infections: clinical and bacteriological study at Tikur Anbessa Specialized University Hospital, Addis Ababa, Ethiopia. Ethiop Med J 2007, 45:171-179.

14. Olatunji, Fadeyi A, Ayanniyi AA, Akanbi AA: Non-gonococcal bacterial agents of conjunctivitis and their antibiotic susceptibility patterns in llorin, Nigeria. Afr J Med Med Sci 2007, 36:243-247.

15. Anguzu JR, Olila D: Drug sensitivity patterns of bacterial isolates from septic post-operative wounds in a regional referral hospital in Uganda. Afr Health Sci 2007, 7:148-154.

16. Nantanda R, Hildenwall H, Peterson S, Kaddu-Mulindwa D, Kalyesubula I, Tumwine JK: Bacterial aetiology and outcome in children with severe pneumonia in Uganda. Ann Trop Paediatr 2008, 28:253-260.

17. Ambe JP, Gasi IS, Mava Y: Review of neonatal infections in University of Maiduguri Teaching Hospital: common bacterial pathogens seen. Niger J Clin Pract 2007, 10:290-293.

18. Legbo JN, Legbo JF: Bacterial isolates from necrotizing fasciitus: a clinicopathological perspective. Niger J Med 2007, 16:143-147.

19. Anah MU, Udo JJ, Ochigbo SO, Abia-Bassey LN: Neonatal septicaemia in Calabar, Nigeria. Trop Doct 2008, 38:126-128. 
20. Odetoyin WB, Aboderin AO, Ikem RT, Kolawole BA, Oyelese AO: Asymptomatic bacteriuria in patients with diabetes mellitus in lle-lfe, South-West, Nigeria. East Afr Med J 2008, 85:18-23.

21. Obidike EO, Anigbo G, Igbodo C: Sensitivity pattern of bacterial isolates in childhood sepsis in clinical practice at Onitsha. Niger J Clin Pract 2009, 12:302-305.

22. Ubani UA: Bacteriology of external ocular infections in Aba, South Eastern Nigeria. Clin Exp Optom 2009, 92:482-489.

23. Shittu AO, Lin J, Kolawole DO: Antimicrobial susceptibility patterns of Staphylococcus aureus and characterization of MRSA in Southwestern Nigeria. WOUNDS 2006, 18:77-84.

24. Okon KO, Basset P, Uba A, Lin J, Oyawoye B, Shittu AO, Blanc DS: Cooccurrence of predominant Panton Valentine leukocidin-positive sequence type (ST) 152 and multidrug-resistant ST241 Staphylococcus aureus clones in Nigerian hospitals. J Clin Microbiol 2009, 47:3000-3003.

25. Ghebremedhin B, Olugbosi MO, Raji AM, Layer F, Bakare RA, Konig B, Konig W: Emergence of a community-associated methicillin-resistant Staphylococcus aureus with unique resistance profile in Southwest of Nigeria. J Clin Microbiol 2009, 47:2975-2980.

26. Adesida S, Boelens H, Babajide B, Kehinde A, Snijders S, van Leeuwen W, Coker A, Verbrugh H, van Belkum A: Major epidemic clones of Staphylococcus aureus in Nigeria. Microb Drug Resist 2005, 11:115-121.

27. Strommenger B, Braulke C, Pasemann B, Schmidt C, Witte W: Multiplex PCR for rapid detection of Staphylococcus aureus isolates suspected to represent community-acquired strains. J Clin Microbiol 2008, 46:582-587.

28. Okeke IN: Factors contributing to the emergence of resistance. In The Resistance Phenomenon in Microbes and Infectious Disease Vectors: Implications for Human Health and Strategies for Containment - Workshop Summary. Edited by: Knobler SL, Lemon SM, Najafi M, Burroughs T. Washington, DC: The National Academies Press; 2003:132-139.

29. Dale GE, Broger C, D'Arcy A, Hartman PG, DeHoogt R, Jolidon S, Kompis I, Labhardt AM, Langen H, Locher H, Page MG, Stuber D, Then RL, Wipf B, Oefner C: A single amino acid substitution in Staphylococcus aureus dihydrofolate reductase determines trimethoprim resistance. J Mol Biol 1997, 266:23-30.

30. Rasigade JP, Laurent F, Lina G, Meugnier H, Bes M, Vandenesch F, Etienne J, Tristan A: Global distribution and evolution of Panton-Valentine leukocidin-positive methicillin-susceptible Staphylococcus aureus, 19812007. J Infect Dis 2010, 201:1589-1597.

31. Breurec S, Fall C, Pouillot R, Boisier P, Brisse S, Diene-Sarr F, Djibo S, Etienne J, Fonkoua MC, Perrier-Gros-Claude JD, Ramarokoto CE, Randrianirina F, Thiberge JM, Zriouil SB, the Working Group on Staphylococcus aureus infections, Garin B, Laurent F: Epidemiology of methicillin-susceptible Staphylococcus aureus lineages in five major African towns: high prevalence of Panton-Valentine leukocidin genes. Clin Microbiol Infect 2010.

32. Holtfreter $S$, Grumann D, Schmudde M, Nguyen HT, Eichler $P$, Strommenger B, Kopron K, Kolata J, Giedrys-Kalemba S, Steinmetz I, Witte W, Bröker BM: Clonal distribution of superantigen genes in clinical Staphylococcus aureus isolates. J Clin Microbiol 2007, 45:2669-2680.

33. Masiuk H, Kopron K, Grumann D, Goerke C, Kolata J, Jursa-Kulesza J, Giedrys-Kalemba S, Broker BM, Holfreter S: Association of recurrent furunculosis with Panton-Valentine Leukocidin and the genetic background of Staphylococcus aureus. J Clin Microbiol 2010, 48:1527-1535.

34. Wiese-Posselt M, Heuck D, Draeger A, Mielke M, Witte W, Ammon A, Hamouda O: Successful termination of a furunculosis outbreak due to lukS-lukF-positive, methicillin-susceptible Staphylococcus aureus in a German village by stringent decolonization, 2002-2005. Clin Infect Dis 2007, 44:e88-95.

35. Goering RV, Shawar RM, Scangarella NE, O'Hara FP, Amrine-Madsen H, West JM, Dalessandro M, Becker JA, Walsh SL, Miller LA, van Horn SF, Thomas ES, Twynholm ME: Molecular epidemiology of methicillinresistant and methicillin-susceptible Staphylococcus aureus isolates from global clinical trials. J Clin Microbiol 2008, 46:2842-2847.

36. Ruimy R, Maiga A, Armand-Lefevre L, Maiga I, Diallo A, Koumare AK, Ouattara K, Soumare S, Gaillard K, Lucet JC, Andremont A, Feil EJ: The carriage population of Staphylococcus aureus from Mali is composed of a combination of pandemic clones and the divergent Panton-Valentine leukocidin-positive genotype ST152. J Bacteriol 2008, 190:3962-3968.

37. Ruimy R, Armand-Lefevre L, Barbier F, Ruppe E, Cocojaru R, Mesli Y, Maiga A, Benkalfat M, Benchouk S, Hassaine H, Dufourcq JB, Nareth C,
Sarthou $J$, Andremont A, Feil EJ: Comparisons between geographically diverse samples of carried Staphylococcus aureus. J Bacteriol 2009, 191:5577-5583.

38. O'Hara FP, Guex N, Word JM, Miller LA, Becker JA, Walsh SL, Scangarella NE, West JM, Shawar RM, Amrine-Madsen H: A geographic variant of the Staphylococcus aureus Panton-Valentine Leukocidin toxin and the origin of community-associated methicillin-resistant S. aureus USA300. J Infect Dis 2008, 197:187-194.

39. Cataldo MA, Taglietti F, Petrosillo N: Methicillin-resistant Staphylococcus aureus: a community health threat. Postgrad Med 2010, 122:16-23.

40. Perez-Roth E, Alcoba-Florez J, Lopez-Aquilar C, Gutierrez-Gonzalez I, RiveroPerez B, Mendez-Alvarez S: Familial furunculosis associated with community-acquired leukocidin-positive methicillin susceptible Staphylococcus aureus ST152. J Clin Microbiol 2010, 48:329-332.

41. Harris SR, Feil EJ, Holden MT, Quail MA, Nickerson EK, Chantratita N, Gardete S, Tavares A, Day N, Lindsay JA, Edgeworth JD, de Lencastre H, Parkhill J, Peacock SJ, Bentley SD: Evolution of MRSA during hospital transmission and intercontinental spread. Science 2010, 327:469-474.

42. Ramdani-Bouguessa N, Bes M, Meugnier H, Forey F, Reverdy ME, Lina G, Vandenesch F, Tazir M, Etienne J: Detection of methicillin-resistant Staphylococcus aureus strains resistant to multiple antibiotics and carrying the Panton-Valentine leukocidin genes in an Algiers hospital. Antimicrob Agents Chemother 2006, 50:1083-1085.

43. Breurec S, Zriouil SB, Fall C, Boisier P, Brisse S, Djibo S, Etienne J, Fonkoua MC, Perrier-Gros-Claude JD, Pouillot R, Ramarokoto CE, Randrianirina F, Tall A, Thiberge JM, the Working Group on Staphylococcus aureus infections, Laurent F, Garin B: Epidemiology of methicillin-resistant Staphylococcus aureus lineages in five major African towns: emergence and spread of atypical clones. Clin Microbiol Infect 2010.

44. Moodley A, Oosthuysen WF, Dusé AG, Marais E, the South African MRSA Surveillance Group: Molecular Characterization of Clinical MethicillinResistant Staphylococcus aureus Isolates in South Africa. J Clin Microbiol 2010, 48:4608-4611.

45. Baranovich T, Zaraket H, Shabana II, Nevzorova V, Turcutyuicov V, Suzuki H: Molecular characterization and susceptibility of methicillin-resistant and methicillin-susceptible Staphylococcus aureus isolates from hospitals and the community in Vladivostok, Russia. Clin Microbiol Infect 2010, 16:575-582.

46. Howden BP, Seemann T, Harrison PF, McEvoy CR, Stanton JA, Rand CJ, Mason CW, Jensen SO, Firth N, Davies JK, Johnson PD, Stinear TP: Complete genome sequence of Staphylococcus aureus JKD6008, an ST239 clone of methicillin-resistant Staphylococcus aureus with intermediate-level vancomycin resistance. J Bacteriol 2010, 192:5848-5849.

47. Deutsches Institut für Normung DIN 58940: Medical Microbiologysusceptibility testing of pathogens to antimicrobial agents. Part 8. Microdilution. General method specific requirements 2004, 342-353.

48. Martineau F, Picard FJ, Ke D, Paradis S, Roy PH, Ouellette M, Bergeron MG: Development of a PCR assay for identification of staphylococci at genus and species levels. J Clin Microbiol 2001, 39:2541-2547.

49. Strommenger B, Kettlitz C, Werner G, Witte W: Multiplex PCR assay for simultaneous detection of nine clinically relevant antibiotic resistance genes in Staphylococcus aureus. J Clin Microbiol 2003, 41:4089-4094.

50. Witte W, Braulke C, Cuny C, Strommenger B, Werner G, Heuck D, Jappe U, Wendt C, Linde HJ, Harmsen D: Emergence of methicillin-resistant Staphylococcus aureus with Panton-Valentine Leukocidin genes in Central Europe. Eur J Clin Microbiol Infect Dis 2005, 24:1-5.

51. Lina G, Durand G, Berchich C, Short B, Meugnier H, Vandenesch F, Etienne J, Enright MC: Staphylococcal chromosome cassette evolution in Staphylococcus aureus inferred from ccr gene complex sequence typing analysis. Clin Microbiol Infect 2006, 12:1175-1184.

52. Harmsen D, Claus H, Witte W, Rothgänger J, Claus H, Turnwald D, Vogel U: Typing of methicillin-resistant Staphylococcus aureus in a university setting by using novel software for spa repeat determination and database management. J Clin Microbiol 2003, 41:5442-5448.

53. Enright MC, Day NP, Davies CE, Peacock SJ, Spratt BG: Multilocus sequence typing for characterization of methicillin-resistant and methicillin-susceptible clones of Staphylococcus aureus. J Clin Microbiol 2000, 38:1008-1015.

doi:10.1186/1471-2180-11-92

Cite this article as: Shittu et al:: Antibiotic resistance and molecular epidemiology of Staphylococcus aureus in Nigeria. BMC Microbiology 2011 11:92. 